УДК 377/378:811.111

https://doi.org/10.32835/2223-5752.2018.16.142-146.

\title{
PODCASTS IN TEACHING ESL
}

Chaikovska Olha,

PhD in Philological Sciences,

Lecturer at Educational and scientific institute for career

development and retraining of State

Agrarian and Engineering University in Podilya,

ORCID ID 0000-0001-9161-4574

e-mail: olgachaikovska@ukr.net

Abstract

\section{KEY WORDS:}

ESL,

podcasts,

professionally-based,

characteristics,

authentic,

flexibility,

motivation,

effectiveness,

up-to-date
The paper reports on research into the integration of podcasts in ESL teaching. This issue is currently of great interest. The article aims to highlight the potential of podcasts in teaching English. The study investigates this issue by comparing and generalizing the existing theoretical material on the topic and examining the effects of podcast application in language learning. The study is concerned with basic characteristics and types of podcasts. Much attention is given to general and professional podcasts, veterinarian and agricultural authentic listening material, in particular. The review of most popular English language podcasts for general and professional usage is given in the study. The author analyzes the strategies for podcast integration in ESL teaching process. It is found that both types of podcasts can be used with the first year university students: general podcasts can be used at preparatory cycle of curriculum, while profession podcasts can be integrated into professionfocused cycle of curriculum. The primary concern of this research is to examine the advantages of integration the podcasts in ESL classroom. The author argues that podcasts could serve as one of the up-to-date effective strategies for ESL learning. It can be concluded that authenticity, multilevelness, ability to promote intrinsic motivation and personal growth, effectiveness (the combination of visual and sound information) and convenience of podcasts make them attractive tool in language learning.
Nowadays modern society demands competitive specialists in any sphere of our life. Foreign language competence is one of the key factors that can influence your future career. A teacher should work hard to adopt new strategies for effective and successful learning the foreign language. Only on the basis of his or her own working experience a teacher may come to a conclusion what approaches to mastering ESL are the best. Today the educational science has no measures due to possible teacher collaboration all over the world with the help of social media technology. Foreign language teachers started to use social media technologies, potential of comics, webinars and on-line courses to make learning the foreign language both effective and interesting. It's not a secret that "modern teenagers are at ease with combining visual and text information". That is why "comics based activities offer the way to reinforce traditional grammar and vocabulary tasks. It was experimentally proved that comics have strong educational potential and can be used almost at each part of the lesson. For example, we can activate prior knowledge and make connections with already learned material, start learning and reflect with the help of comics (Chaikovska, 2018, p.8). Another digital resource that can benefit both the process of learning and self-study is a webinar. Academics state that "flexibility, interactivity, cost-effectiveness, long-time value made online workshops" and webinars "number one training in the world" (Chaikovskaya, 2017, p.240).

One of the up-to-date tools for successful language learning is podcasts. People all over the world try to do the best of their time and not to lose a minute. You can listen to the information you need while commuting to work or study, driving a car, walking in the park and doing routine work. Scientists proved that brain works better while person is walking, so you have an opportunity to remember new words and phrases and to practice your listening.

So, the aim of the study is to analyze podcasts that can be used in both general and professionallybased English learning. The article also determines the benefits of podcasts in ESL teaching.

This term was created by bloggers to determine the information in audio format. The sites that 
contain podcasts remind us social media: they have audio books, interviews and audio texts on history, trade, and politics either in monologue or dialogue form.

Podcasting (a portmanteau of the words iPod and broadcasting) is the name given to the publishing of audio (usually $\mathrm{mp} 3$ files) via the Internet, designed to be downloaded and listened to on a portable $\mathrm{mp} 3$ player of any type, or on a personal computer (Teaching English, 2018). Listening comprehension is one of the most difficult tasks for ESL students. Recently podcasts generated a lot of interest due to their ability to be integrated in studying to improve student listening, speaking and reading skills. The survey was conducted on the basis of the papers written by the following writers: Chester A., Buntine A., Hammond K., Atkinson L., Solomatina A. G., Salin B. S., Dmitriev D. V., Meshcheryakov A. S. and podcasts.

Not all types of podcasts can be implemented in ESL classroom. Experienced podcast users advise to start with the resources created by teachers. Moreover, we should realize for what purpose we use podcasts. So, if we are going improve general skills in the English language there are a lot of podcasts to use. For example, "This American Life" is the most popular podcast in the United States. According to English language and Culture blog "FluentU" there are approximately 1 million downloads of each episode (Fluent English, 2018). The podcast has the similar format to radio programme. Interviews with native speakers, accents and different speeds of speaking will help to practice listening skills.

"The English we speak" of BBC (British Broadcasting Corporation) is the English language learning podcast and is focused on everyday phrases, idioms and slang. New podcasts appear every week. And what is important the speaking speed is bit slower than in usual life.

In "English class 101 by innovative language" podcast you can choose series for all levels. Podcasts have several sections here: various scenes acted out by hosts (be the way, there is an opportunity to hear the information at a lower speed), presentation of culturally relevant information, definitions of the words and phrases and even grammar.

Elementary podcasts by British Council contain lessons for beginner and intermediate learners. The time of each lesson is about 25 minutes, but if the student gets tired of listening he/she can easily pause. One of the benefits of British Council Elementary podcasts is that there are a lot of materials on the topic, so you have a chance to read them beforehand. The students can easily download podcasts from British Council and receive new episodes every week. The topics themselves are very interesting: "Whose game is it?" (the podcast describes the changes that took place in football game), "New Year's revolution" (the listener will know about the traditions of celebrating New Year in Scotland), the podcast "The Iron Lady" is devoted to Margaret Thatcher and tells the story how she became an "Iron Lady", in the episode "Backseat drivers" the students will hear about the British love of driving from classic to Formula 1 racing, about great British cheeses, about British love of books. The students will be able to find out how tea is making a comeback to the UK, how the biggest names in British music were created. The survey conveyed makes it possible to confirm that podcasts help to develop not only listening and speaking skills to learn new vocabulary, but also learn basic characteristics of other cultures. It will help to avoid misunderstanding in future and communicate effectively. Authentic listening tasks should be given to the students of all level: from beginners to advanced ones. What we especially like is a short time of podcasts (2-5 minutes), so the students won't be bored and it won't be difficult for them to learn the words and phrases in the podcast. As soon as you press the button "copy" the transcript appears on the screen. The text is divided into passages one or two sentences long. And the passage is being read at the moment turns, in our case, green. The change in color helps to focus student's attention on the information that is being read by the host.

The procedure of studying English on the basis of podcasts in class can differ according to the language level of the listeners. What is important, students need time to learn how to read, listen and watch and take notes on podcasts. A teacher should realize that most students may have never been engaged with podcasts. Firstly, it's desirable to listen to the podcast and scan it once for advanced students and twice or even three times for elementary level students. Then the teacher can stop each passage and ask the students to repeat after the reader, focus on new words, grammar constructions. A teacher can develop a set of training exercises: true or false, multiple choices, open-ended questions, put the paragraphs into correct order, complete the sentences about the 
text, missing words. At home students can listen to the same podcast and do the tasks from the list above. Advanced students can create podcasts themselves/ But before that a teacher has to show the tools for recording the podcast, interviewing people, adding music, combining the slides and etc.

Alongside with general topics we can find Professionals podcasts at British Council. Episodes concern the job application (a journalist is giving an advice on interviewing techniques, how to resolve dispute at work with the help of mediator) and some major based information. For instance, students of Economics Department can listen to a business management expert talking about the price that some companies have to pay when they fail to address diversity-related risks, Professor of Business Studies talks about the subject of motivation or the future of Martha Stewart brand is discussed. These are the podcasts that can be easily adapted to teaching the students of Economics Department. Moreover, we should take into consideration the fact that English is studied only during the first year at technical universities. So university students can continue their self-study with the help of podcasts.

But only a narrow circle of people know about existing advanced professionally based English podcasts. I teach English at State Agrarian and Engineering University of Podilya and students major in Agriculture and Agronomy, Veterinary Medicine, Mechanical Engineering study there. So we had no difficulties to find podcasts suitable for future specialists in Veterinary Medicine, Agronomy. These podcasts can be used for university students, Master students and people who just started their career and need English for professional development. Veterinary clinical podcasts have a lot of interviews with specialists in the sphere of veterinary medicine. If you are about to start your veterinary career and want to learn more about Equine anesthesia, Hypoglycemia, Pericardial Effusion, Technical aspects of ultrasonography these podcasts are for you. The VET girl Veterinary Continuing Education Podcasts are designed learn clinical veterinary medicine with style, passion, and efficiency (Best Veterinary Podcasts, 2018). University ESL teachers can choose certain the podcasts appropriate for student level. For example such topics as "How to become veterinarian", "Parasites", "Nutrition", "Small animal vaccinations" can be used with the firstyear students of Veterinary Medicine Faculty.
There are many podcasts that can assist major subjects at Agricultural Department. Successful Farming (Successful Farming, 2018) is a kind of on-line magazine where can you hear up-to-date news from experts and leaders in the agricultural industry. The students who are keen on their future profession such topic as "Anatomy of a seed treatment". The host Jodi Henke talks with Syngenta Seed Care Specialist Chad Vest about how and why seeds are treated, how to choose what treatments you need, and does seed color matter? The following podcast "Getting the most out of your combiners and corn heads" will be interested for students who deal with agricultural machines. They will not only be able to converse with their colleagues, but to learn how to harvest down corn, prevent ear and grain losses.

The analysis of how podcasts work allows us to confirm that there are many benefits of using podcasts. First of all, in podcasts we deal with authentic texts that are the information the listener hears is not for the purpose of language-teaching. This is an opportunity to explore how English is really used by native speakers. Authentic texts have to be used in ESL lessons to give the students more of a sense how English is really used.

Second of all, podcasts are multifunctional. They help to develop several skills at a time: listening, reading (podcasts often have transcripts (a written version of the audio). Podcasts also influence writing and speaking. Students who listen to the podcasts can imitate the manner and intonation the native speakers have. In addition, podcasts provide knowledge on culture, traditions.

Podcasts motivate the students. The topics of general and profession podcasts are diverse and interesting, so the students work with podcasts because it is enjoyable. Here we deal with intrinsic motivation when the student wants to do podcasts not because of any rewards or grades, but because of own interest. If you subscribe the podcasts, you regularly receive additional information, resources, vocabulary tasks, recordings and worksheets for mastering English. Consequently, if a student is involved in the process of learning and has the sense that he/she is the part of the team it certainly assists the effectiveness of ESL studying.

At the same time the student is independent and can choose the topic he/she likes, the speed of the dialogue or monologue and the time to listen to podcasts. So called flexibility of podcasts makes them very popular among English language learners. 
We can't but mention that podcasts can be used with students of all levels of language competence. It's a teacher who has to choose the podcasts of appropriate level. If there are multileveled students in one group, a teacher may choose the podcast of average complexity and adapt the tasks for mixed ability classroom that is for stronger and weaker students.

The simultaneous absorbing of visual and sound information makes podcasts one of the effective tools that can benefit the studying process. Authentic listening is usually accompanied not only by transcripts, but also by visuals. And some specialists contend that visuals tend to help in understanding unknown words with the help of gestures and facial expressions. Besides, most podcasts are absolutely free, so it is really very convenient for students.

To sum up, foreign language learning strategies are never the same. We live in era of computer technology, so some of them loose their actuality and turn out to be not so effective. Academics try to find and provide innovative and more effective strategies in education process. The author of the study argues that podcasts should be used in ESL teaching as one of highly effective techniques in language studying. Teaching with podcasts can be rewarding and interesting. English language podcasts can be used either at schools and universities, English language courses, speaking clubs, extra curriculum activities or professionallybased English language courses. As far as university study is concerned the term of foreign language learning depends on the type of educational establishment. For instance, the English language is studied only during the first year at university, sometimes a year and a half. Foreign language curriculum includes two cycles: the preparatory and specialized. The study has confirmed that podcasts related to the general topics can be used in the preparatory cycle and profession-based ones in the specialized cycle. The article provided the analysis of most popular podcasts that can be adapted in teaching ESL. Besides, the procedure for podcast application in education process was highlighted. The author suggests that simultaneous reading and listening, repetition of words; vocabulary and grammar activities can definitely offer numerous benefits to learning English. Such characteristics of podcasts as authenticity, multi functionality, ability to motivate, flexibility and quick absorbing of information make it a very perspective teaching strategy.

\section{Література}

1. Veterinary Podcasts, 2018. VETgirl Veterinary Continuing Education Podcasts. [online] Available at:<https://player.fm/series/1916964https://player. fm/series/1916964> [14 Жовтень 2018].

2. Chaikovska, O., 2018. Benefits of teaching ESL through comic strips. Web of Scholar, 4(19), c. $8-12$.

3. Chaikovskaya, O.V., 2017. How webinars work to engage and motivate teachers towards success. B: T.I. Раковчен, ред. Наука, освіта, культура: науково-практична конференція, присвячена 26-річчю Комратського державного університету, № 2, Комрат, Молдова, с. 238-240.

4. Chester, A., Buntine A., Hammond K. and Atkinson L., 2011. Podcasting in Education: Student Attitudes, Behavior and Self-Efficacy. Educational Technology and Society, 14 (2), pp. 236-247.

5. Fluent English, 2018. Native English
Podcasts for learning English. [online] Available at: <https://www.fluentu.com/blog/english/learnesl-english-podcasts/> [4 Вересень 2018].

6. Салин, БС, 2010. Деякі аспекти використання подкастів в навчанні англійської мови. Сучасні проблеми науки і освіти, 4, с. 9193.

7. Соломатіна, А.Г., 2011. Методика розвитку навичок говоріння й аудіювання учнів шляхом учбових подкастів. Кандидат наук, Тамбов.

8. Successful Farming, 2018. [online] Available at: Successful farming podcasts. Доступно: < https://www.agriculture.com/podcast/successfulfarming-podcast $>$ [4 Листопад 2018].

9. Teaching English, 2018. [online] Available at: Podcasting for ESL. Доступно: <https://www. teachingenglish.org.uk/article/podcasting-elt.> [16 Жовтень 2018]. 


\title{
Подкасти у викладанні англійської мови
}

\author{
Ольга Чайковська, \\ кандидат філологічних наук, \\ викладач навчально-наукового інституту \\ підвищення кваліфікаиії та перепідготовки \\ Подільського державного \\ аграрно-технічного університету
}

\section{КЛЮЧОВІ СЛОВА:}

професійна освіта, англійська мова, подкасти, мультифункціональність, мотивація

Реферат

Проблема інтеграції подкастів у процес викладання англійської як другої іноземної мови на сьогодні $є$ дуже актуальною. Стаття має на меті висвітлити потенціал подкастів у викладанні англійської мови. Проблему розглянуто шляхом порівняння та узагальнення існуючого теоретичного матеріалу із теми та дослідження результатів практичного застосування подкастів у вивченні мови, в якому виявлено основні характеристики та види подкастів. Особливу увагу приділено загально- та професійно-спрямованим подкастам, зокрема ветеринарним та сільськогосподарським аудіоматеріалам. У дослідженні здійснено огляд найпопулярніших подкастів з англійської мови. Автор аналізує стратегії інтеграції подкастів в освітній процес. Виявляється, що обидва типи подкастів можна використовувати у навчанні студентів першого курсу університетів технічного спрямування: загальні подкасти використовуються у підготовчому циклі навчальної програми; водночас, професійні подкасти можуть бути інтегровані в професійно-спрямований цикл освітньої програми. Основною метою цього дослідження $є$ вивчення переваг використання подкастів на заняттях з англійської мови. З'ясовано, що подкасти $€$ сучасними ефективними стратегіями у викладанні англійської. Можна зробити висновок, що автентичність, мультифункціональність, здатність сприяти внутрішній мотивації та особистому зростання (поєднання візуальних та слухових сигналів ) та зручність у використанні перетворює подкасти на привабливий інструмент процесу мовлення.

\section{References}

1. Veterinary Podcasts, 2018. VETgirl Veterinary Continuing Education Podcasts. [online] Available at: $<$ https://player.fm/series/1916964https://player. fm/series/1916964> [14 Жовтень 2018].

2. Chaikovska, O., 2018. Benefits of teaching ESL through comic strips. Web of Scholar, 4(19), c. $8-12$.

3. Chaikovskaya, O.V., 2017. How webinars work to engage and motivate teachers towards success. V: T.I. Rakovchen, red. Nauka, osvita, kultura: naukovo-praktychna konferentsiia, prysviachena 26-richchiu Komratskoho derzhavnoho universytetu, № 2, Komrat, Moldova, s. $238-240$.

4. Chester, A., Buntine A., Hammond K. and Atkinson L., 2011. Podcasting in Education: Student Attitudes, Behavior and Self-Efficacy. Educational Technology and Society, 14 (2), pp. 236-247.

5. Fluent English, 2018. Native English
Podcasts for learning English. [online] Available at: $<$ https://www.fluentu.com/blog/english/learnesl-english-podcasts/> [4 Veresen 2018].

6. Salyn, BS, 2010. Deiaki aspekty vykorystannia podkastiv $\mathrm{v}$ navchanni anhliiskoi movy. Suchasni problemy nauky i osvity, 4, s. 9193.

7. Solomatina, A.H., 2011. Metodyka rozvytku navychok hovorinnia y audiiuvannia uchniv shliakhom uchbovykh podkastiv. Kandydat nauk, Tambov.

8. Successful Farming, 2018. [online] Available at: Successful farming podcasts. Доступно: < https://www.agriculture.com/podcast/successfulfarming-podcast $>$ [4 Lystopad 2018].

9.Teaching English, 2018. [online] Available at: Podcasting for ESL. Доступно: <https://www. teachingenglish.org.uk/article/podcasting-elt.> [16 Zhovten 2018]. 